\title{
STUDY OF FLY ASH GEOPOLYMER AND FLY ASH/SLAG GEOPOLYMER IN TERM OF PHYSICAL AND MECHANICAL PROPERTIES
}

\author{
Ng HUI-TENG ${ }^{1}$, Heah CHENG-YONG ${ }^{1,2, *}$, Mold Mustafa Al Bakri ABDULLAH ${ }^{1}$, \\ Ng YONG-SING ${ }^{1}$, Ridho BAYUAJI ${ }^{3}$ \\ ${ }^{I}$ Centre of Excellence Geopolymer and Green Technology (CEGeoGTech), School of Materials Engineering, \\ Universiti Malaysia Perlis (UniMAP), 01000 Kangar, Perlis, Malaysia. \\ ${ }^{2}$ Faculty of Engineering Technology, Universiti Malaysia Perlis (UniMAP), 02100 Padang Besar, Perlis, Malaysia. \\ ${ }^{3}$ Civil Engineering Department, Institut Teknologi Sepuluh Nopember, Indonesia
}

\begin{abstract}
This article presents the mixing parameters of fly ash geopolymer based on $\mathrm{NaOH}$ concentration $(6 \mathrm{M}-14 \mathrm{M}), \mathrm{S} / \mathrm{L}$ ratio $\left(1.0\right.$ - 3.5), $\mathrm{Na}_{2} \mathrm{SiO}_{3} / \mathrm{NaOH}$ ratio (1.0 - 3.0) and ladle furnace slag replacement (10\%-40\%). Additionally, a comparative study between fly ash geopolymer and fly ash/slag geopolymer with respect to the bulk density, water absorption, apparent porosity and compressive strength were investigated. The general bulk densities of fly ash/slag geopolymer were higher than fly ash geopolymer. The apparent porosity and water absorption of fly ash/slag geopolymers were comparatively lower than fly ash geopolymers. High compressive strength achieved by fly ash/slag geopolymer was contributed by high bulk density and low apparent porosity and water absorption. In other words, fly ash geopolymer obtained lower strength was due to lower bulk density and higher apparent porosity and water absorption.
\end{abstract}

Keywords: parameters, fly ash geopolymer, fly ash/slag geopolymer

\section{Introduction}

Nowadays, industrial by-products are increasing attention due to its disposal problem where they could occupy the landfill space. Fly ash and slag are some types of industrial solid wastes. Fly ash can be sorted by Class F (fine) and Class C (coarse) [1]. Slag can be classified by iron slag (ground-granulated blast furnace slag [2]) and steel slag (basic oxygen furnace slag, electric arc furnace slag, and ladle furnace slag [3]). The current daily production of fly ash and slag in Malaysia itself recorded 1,620 tons [4] and 7.5 tons [5], respectively. Hence, recycling the fly ash and slag in the construction field is a strategic way to solve the issues of disposal at the same time decrease the environmental impacts.

Numerous researchers have been utilized various aluminosilicate materials (such as metakaolin [6], kaolin [7], fly ash [8] and slag [3]) and alkaline solution (such as sodium and potassium-based [9]) to synthesize aluminosilicate geopolymer. Hence, the type of aluminosilicate sources used, the type of alkaline activator used and the mixing parameters are making attention nowadays. For instance, sodium hydroxide $(\mathrm{NaOH})$ and potassium hydroxide $(\mathrm{KOH})$ concentration were a key parameter affecting the mechanical strength [10-12]. Cai et al. [12] concluded that increasing $\mathrm{KOH}$ concentration between $4 \mathrm{M}$ to $16 \mathrm{M}$ based on metakaolin geopolymer increased the compressive strength from $42 \mathrm{MPa}$ to $60 \mathrm{MPa}$. Narimani Zamanabadi et al. [10] studied the influence of using $\mathrm{NaOH}$ concentration of $8 \mathrm{M}, 12 \mathrm{M}$ and $16 \mathrm{M}$ to synthesize slag geopolymer and revealed that $12 \mathrm{M}$ was optimized with the compressive strength of 47.6 
MPa. For fly ash geopolymer, the increase of $\mathrm{NaOH}$ concentration $(6 \mathrm{M}, 8 \mathrm{M}$ and $10 \mathrm{M})$ improved the compressive strength $(39.1 \mathrm{MPa})$ at $10 \mathrm{M}$ [11]. However, further increased the $\mathrm{NaOH}$ concentration after the optimum molarity could deteriorate the strength of geopolymers due to the severity of efflorescence increased [13].

Besides, other researchers [14-16] suggested that the solid to liquid (S/L) ratio could affect the mechanical strength. Arafa et al. [14] studied the various S/L ratio (1.7 to 2.7) on fly ash geopolymer and suggested that the increase of compressive strength $(87 \mathrm{MPa})$ was attributed to the density gained when increasing $\mathrm{S} / \mathrm{L}$ ratio up to 2.5 . Moreover, Ling et al. [15] focused on $\mathrm{S} / \mathrm{L}$ ratio in the range of 1.67 to 3.03 and concluded that increasing this ratio tends to positively influence the compressive strength from $40 \mathrm{MPa}$ to $75 \mathrm{MPa}$ on fly ash geopolymer. Some of the researchers [16] also concentrated on the $\mathrm{S} / \mathrm{L}$ ratio based on geopolymer mortar and concrete. They stated that increasing $\mathrm{S} / \mathrm{L}$ ratio up to 2.22 contributed to the compressive strength of geopolymer mortar with $25.83 \mathrm{MPa}$ whereas the optimum strength $(11.5 \mathrm{MPa})$ of geopolymer concrete obtained at 3.03 of $\mathrm{S} / \mathrm{L}$ ratio. However, further increase the $\mathrm{S} / \mathrm{L}$ ratio tend to increase setting time [17] and viscosity [14] which degrade the strength of geopolymer.

For the alkaline activator, the combination of alkali hydroxide and soluble silicate positively influenced the organization of the geopolymeric structure and contributed to the strength gain as compared to the solely alkaline hydroxide used [18, 19]. Alkaline hydroxide is used to dissolute the aluminosilicate sources while soluble silicate played the role of binder [20]. The most commonly used alkaline solutions are mixing of hydroxide (sodium or potassium) and silicate (sodium or potassium) such as $\mathrm{NaOH}$ mixed with $\mathrm{Na}_{2} \mathrm{SiO}_{3}$ [9]. Zamanabadi et al. [10] used 1.0, 2.5, and 4.0 of $\mathrm{Na}_{2} \mathrm{SiO}_{3} / \mathrm{NaOH}$ ratio to activate the slag geopolymer and suggested that 2.5 provided the optimum compressive strength with $47.6 \mathrm{MPa}$ as soluble $\mathrm{Si}$ from $\mathrm{Na}_{2} \mathrm{SiO}_{3}$ altered the reaction of kinetics and indirectly improved the condensation process [21]. Saloma et al. [22] studied the ranges from 2.50 to 3.25 of $\mathrm{Na}_{2} \mathrm{SiO}_{3} / \mathrm{NaOH}$ ratio based on fly ash geopolymer and showed an increment compressive strength from 50MPa to $70 \mathrm{MPa}$ up to 2.75 of $\mathrm{Na}_{2} \mathrm{SiO}_{3} / \mathrm{NaOH}$ ratio. However, high viscosity [23] and long setting time [24] caused strength dropped when higher $\mathrm{Na}_{2} \mathrm{SiO}_{3} / \mathrm{NaOH}$ ratio was used.

Meanwhile, plenty of researches have been utilized two or more precursors to synthesize aluminosilicate geopolymer such as fly ash/slag-based [25], fly ash/metakaolin-based [26], fly ash/kaolin-based [27] and slag/metakaolin-based [28]. The performance of these geopolymers was usually better than the sole precursor used. For instance, some researchers [29] investigated that incorporating ground-granulated blast furnace slag into fly ash geopolymer could enhance the mechanical performance and microstructure of geopolymer. Niklioć et al. [25] utilized electric arc furnace slag to replace with fly ash geopolymer and it was beneficial to the sample as strength improved.

However, the use of ladle furnace slag to substitute fly ash geopolymer is still lack. Wang et al. [30] utilized ladle furnace slag to synthesize geopolymer and successfully obtained a high strength. Hence, ladle furnace slag is believed to have potential use to incorporate into fly ash geopolymer. In this paper, the objective is to investigate the mixing parameters $(\mathrm{NaOH}$ concentration, $\mathrm{S} / \mathrm{L}$ ratio, $\mathrm{Na}_{2} \mathrm{SiO}_{3} / \mathrm{NaOH}$ ratio and ladle furnace slag replacement) towards fly ash geopolymer by physical and mechanical testing included bulk density, apparent porosity, water absorption and compressive strength.

\section{Materials and Methods}

The aluminosilicate materials used were fly ash and ladle furnace slag. They were supplied in the form of grey powder. The chemical composition of aluminosilicate materials was acquired from X-ray fluorescence (XRF) analysis. The main compounds of fly ash were $\mathrm{SiO}_{2}$ and $\mathrm{Al}_{2} \mathrm{O}_{3}$. The $\mathrm{CaO}$ content of fly ash was $3.89 \%$ which is less than $20 \%$, and summation of the $\mathrm{SiO}_{2}, \mathrm{Al}_{2} \mathrm{O}_{3}$ and $\mathrm{Fe}_{2} \mathrm{O}_{3}$ content were more than $70 \%$ which is $91.16 \%$, and hence, these are evident to classify 
that fly ash as Class F according to the description of ASTM C618 [31]. Besides, the main compound of slag was $\mathrm{CaO}$ which indicated the grey colour of slag. Slag further contained $21.3 \%$ of $\mathrm{SiO}_{2}$ and $2.3 \%$ of $\mathrm{Al}_{2} \mathrm{O}_{3}$.

Table 1. Chemical composition of fly ash and slag, as determined using XRF analysis

\begin{tabular}{lcccccccc}
\hline Compound & $\mathrm{SiO}_{2}$ & $\mathrm{Al}_{2} \mathrm{O}_{3}$ & $\mathrm{CaO}$ & $\mathrm{Fe}_{2} \mathrm{O}_{3}$ & $\mathrm{TiO}_{2}$ & $\mathrm{~K}_{2} \mathrm{O}$ & $\mathrm{MgO}$ & Other \\
\hline Fly ash (wt.\%) & 56.3 & 28.00 & 3.89 & 6.86 & 2.17 & 1.49 & - & 1.29 \\
\hline Slag (wt.\%) & 21.3 & 2.30 & 63.59 & 8.08 & 0.5 & - & 2.6 & 1.63 \\
\hline
\end{tabular}

The alkaline solution used was the combination of sodium hydroxide $(\mathrm{NaOH})$ and sodium silicate $\left(\mathrm{Na}_{2} \mathrm{SiO}_{3}\right)$. $\mathrm{NaOH}$ was in the form of white caustic soda pellets with $99 \%$ purity and supplied by Sigma-Alrich, Germany with the brand name of $\mathrm{HmbG}^{\circledR}$. The colourless of $\mathrm{Na}_{2} \mathrm{SiO}_{3}$ solution was collected from South Pacific Chemicals Industries Sdn. Bhd. (SPCI), Malaysia with the chemical compositions of $\mathrm{SiO}_{2}(30.1 \%), \mathrm{Na}_{2} \mathrm{O}(9.4 \%)$ and $\mathrm{H}_{2} \mathrm{O}(60.5 \%)$. The specific gravity and viscosity of $\mathrm{Na}_{2} \mathrm{SiO}_{3}$ at $20^{\circ} \mathrm{C}$ were $1.4 \mathrm{~g} / \mathrm{cm}^{3}$ and $0.4 \mathrm{~Pa} . \mathrm{s}$, respectively.

Geopolymers were sorted by two types of geopolymers which are fly ash geopolymer and fly ash/slag geopolymers. Fly ash geopolymer was prepared by mixing of full fly ash with alkali activator whereby fly ash/slag geopolymer was mixed by fly ash and slag with the proportion of 90:10, 80:20, 70:30 and 60:40 with alkali activator. $\mathrm{NaOH}$ pellets were mixed with distilled water and put into a volumetric flask under room temperature in order to cool down. After combined the $\mathrm{NaOH}$ and $\mathrm{Na}_{2} \mathrm{SiO}_{3}$, the samples were kept for 24 hours to achieve equilibrium under room temperature. This solution further mixed with fly ash and slag powder and stirred well for 15 minutes by using a mechanical mixer. Fly ash geopolymer was formulated with $\mathrm{NaOH}$ concentration $(6 \mathrm{M}, 8 \mathrm{M}, 10 \mathrm{M}, 12 \mathrm{M}$ and $14 \mathrm{M}), \mathrm{S} / \mathrm{L}$ ratio $(1.0,1.5,2.0,2.5,3.0$ and 3.5), $\mathrm{Na}_{2} \mathrm{SiO}_{3} / \mathrm{NaOH}$ ratio $(1.0,1.5,2.0,2.5$ and 3.0) and slag replacement (10\%, 20\%, $30 \%$ and 40\%).

After mixing, the geopolymer pastes were then rapidly poured into cube $(50 \times 50 \times 50 \mathrm{~mm})$ plastic moulds and hence, compacted and tamped the paste based on the description of ASTM $\mathrm{C} 109$ [32]. Afterward, the samples were pre-curing at room temperature $\left(25^{\circ} \mathrm{C}\right)$ for one day and further went through the curing process at $60^{\circ} \mathrm{C}$ for 24 hours in an oven which was manufactured by Young Chenn Instruments model types $\mathrm{COH}-545$. The exposed portion of the samples was covered by plastic in order to prevent the moisture escape during the curing stage. After the curing process, all samples were removed from oven and further kept at room temperature for 28 days before undergoing testing.

To evaluate the bulk densities, measured the mass and dimensions of the samples based on BS EN 12390-7 [33] as shown in equation 1. To clarify the water absorption, measured the mass (wet and dry) of the specimens whereby further measured the suspended mass for apparent porosity as shown in Equation 2 and Equation 3 according to ASTM C642 [34]. The test of compressive strength was to determine the highest resistance of a sample who can resist the axial load by using a Mechanical Tester with a constant rate of $5 \mathrm{~mm} / \mathrm{min}$. Three specimens were tested for each ratio.

$$
\begin{gathered}
\text { Bulk density }\left(\mathrm{kg} / \mathrm{m}^{3}\right)=\frac{\text { Mass }}{\text { Volume }} \\
\text { Water absorption }(\%)=\frac{\text { Wet weight-Dryweight }}{\text { Dryweight }} \cdot 100 \\
\text { Apparent porosity }(\%)=\frac{\text { Wet weight-Dryweight }}{\text { Wet weight-Suspended weight }} \cdot 100
\end{gathered}
$$




\section{Results and Discussion}

\section{Bulk Density}

Fig. 1 showed the bulk density of fly ash geopolymers with various parameters. In general, the bulk densities of fly ash geopolymer and fly ash/slag geopolymer optimized at a certain point ( $8 \mathrm{M}$ of $\mathrm{NaOH}$ concentration, 3.0 of $\mathrm{S} / \mathrm{L}$ ratio, 1.5 of $\mathrm{Na}_{2} \mathrm{SiO}_{3} / \mathrm{NaOH}$ ratio and $20 \%$ of slag replacement) and then reduced. The bulk densities of fly ash geopolymer (Fig. 1a-c) were in the range between $1568.33 \mathrm{~kg} / \mathrm{m}^{3}$ and $2050 \mathrm{~kg} / \mathrm{m}^{3}$. This observation was consistent with the density result of around $2000 \mathrm{~kg} / \mathrm{m}^{3}$ which was reviewed by Muthu Kumar \& Ramamurthy [35]. However, the overall bulk densities of fly ash $/ \mathrm{slag}$ geopolymer $\left(2055 \mathrm{~kg} / \mathrm{m}^{3}\right.$ to $\left.2100 \mathrm{~kg} / \mathrm{m}^{3}\right)$ were comparatively higher than those fly ash geopolymer alone as shown in Fig. 1d. This is because the slag source material consisted of $1238 \mathrm{~kg} / \mathrm{m}^{3}$ density which was heavier than fly ash source materials $\left(1168 \mathrm{~kg} / \mathrm{m}^{3}\right)$. It was in alignment with Pilehvar et al. [36].
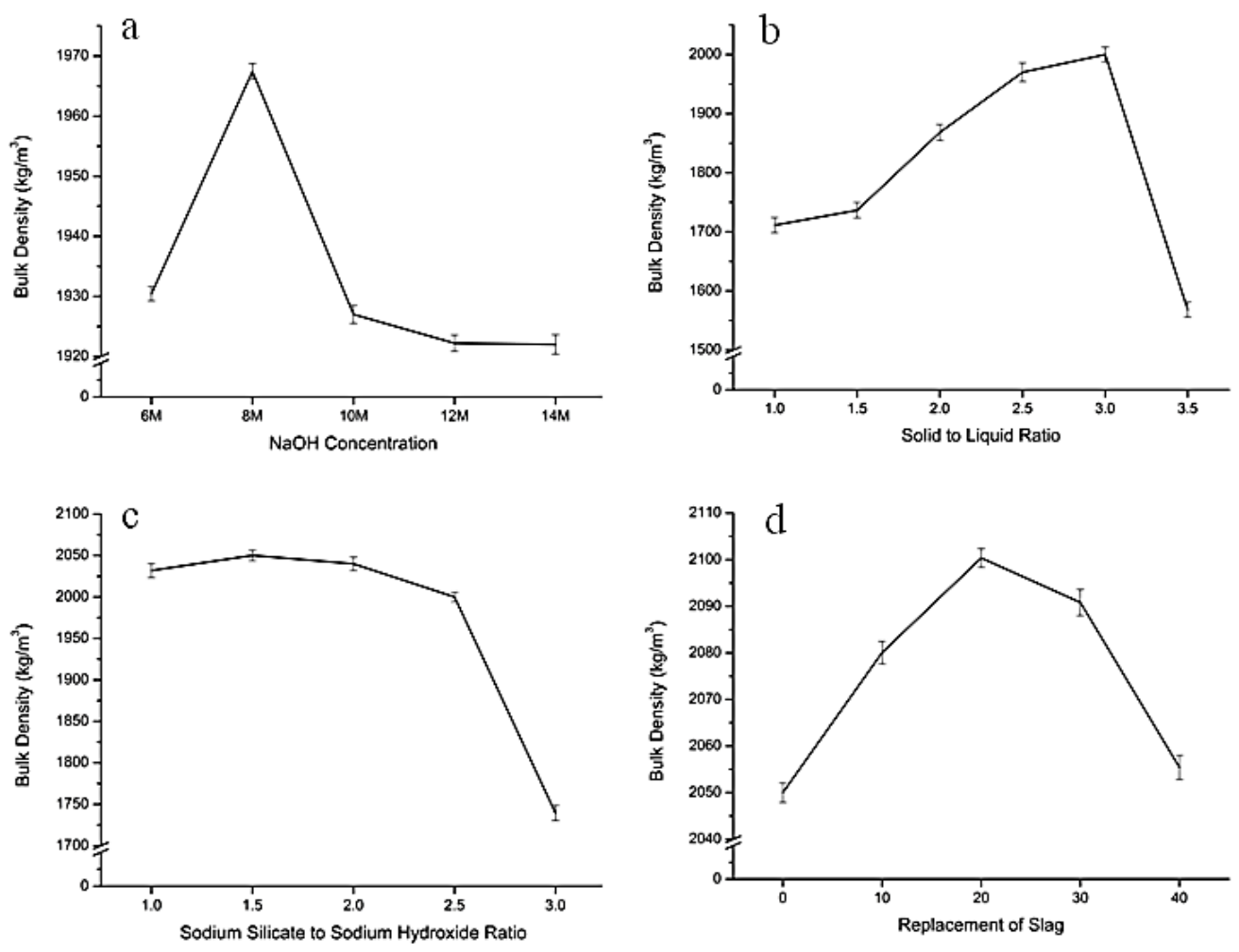

Fig. 1. Bulk density of fly ash geopolymer with a) $\mathrm{NaOH}$ concentration, b) $\mathrm{S} / \mathrm{L}$ ratios, c) $\mathrm{Na}_{2} \mathrm{SiO}_{3} / \mathrm{NaOH}$ ratios and d) slag replacement.

As a comparison, similar trend was conducted by Patankar et al. [37] when increasing $\mathrm{NaOH}$ concentration in fly ash geopolymer mortar. The densities were in the range between $2157.65 \mathrm{~kg} / \mathrm{m}^{3}$ to $2215.67 \mathrm{~kg} / \mathrm{m}^{3}$ and these denser ranges were due to the addition of filler sand. Next, Rahim et al. [17] investigated the S/L ratio from 3 to 5 on fly ash geopolymer and cured for one day. They obtained the bulk densities ranges from $2900 \mathrm{~kg} / \mathrm{m}^{3}$ to $3600 \mathrm{~kg} / \mathrm{m}^{3}$ whereby similar trends observed. Various densities range achieved can be explained by the data collection at varying aging days. Besides, Kamseu et al. [18] concluded that increase $\mathrm{Na}_{2} \mathrm{SiO}_{3}$ reduced the bulk density of rice husk ash/metakaolin geopolymer composite from $1700 \mathrm{~kg} / \mathrm{m}^{3}$ to $1420 \mathrm{~kg} / \mathrm{m}^{3}$. Various trends obtained might be due to different aluminosilicate source used. Furthermore, Guo 
\& Yang [38] studied the fly ash/slag geopolymer composite with the addition of fiber. They revealed that by increasing slag content from $7 \%$ to $28 \%$ tended to increase the apparent density $\left(1650 \mathrm{~kg} / \mathrm{m}^{3}\right.$ to $\left.1850 \mathrm{~kg} / \mathrm{m}^{3}\right)$ continuously. The trend was different due to the presence of fiber in their study.

\section{Apparent Porosity and Water Absorption}

Fig. 2 displayed the apparent porosity and water absorption with various parameters on fly ash geopolymer. Overall, the results of water absorption follow the trend of apparent porosity results due to the higher porosity content tended to absorbed more water in the samples. The overall apparent porosity and water absorption of fly ash geopolymer were between $19 \%$ to $40 \%$ and $9 \%$ to $22 \%$, respectively.
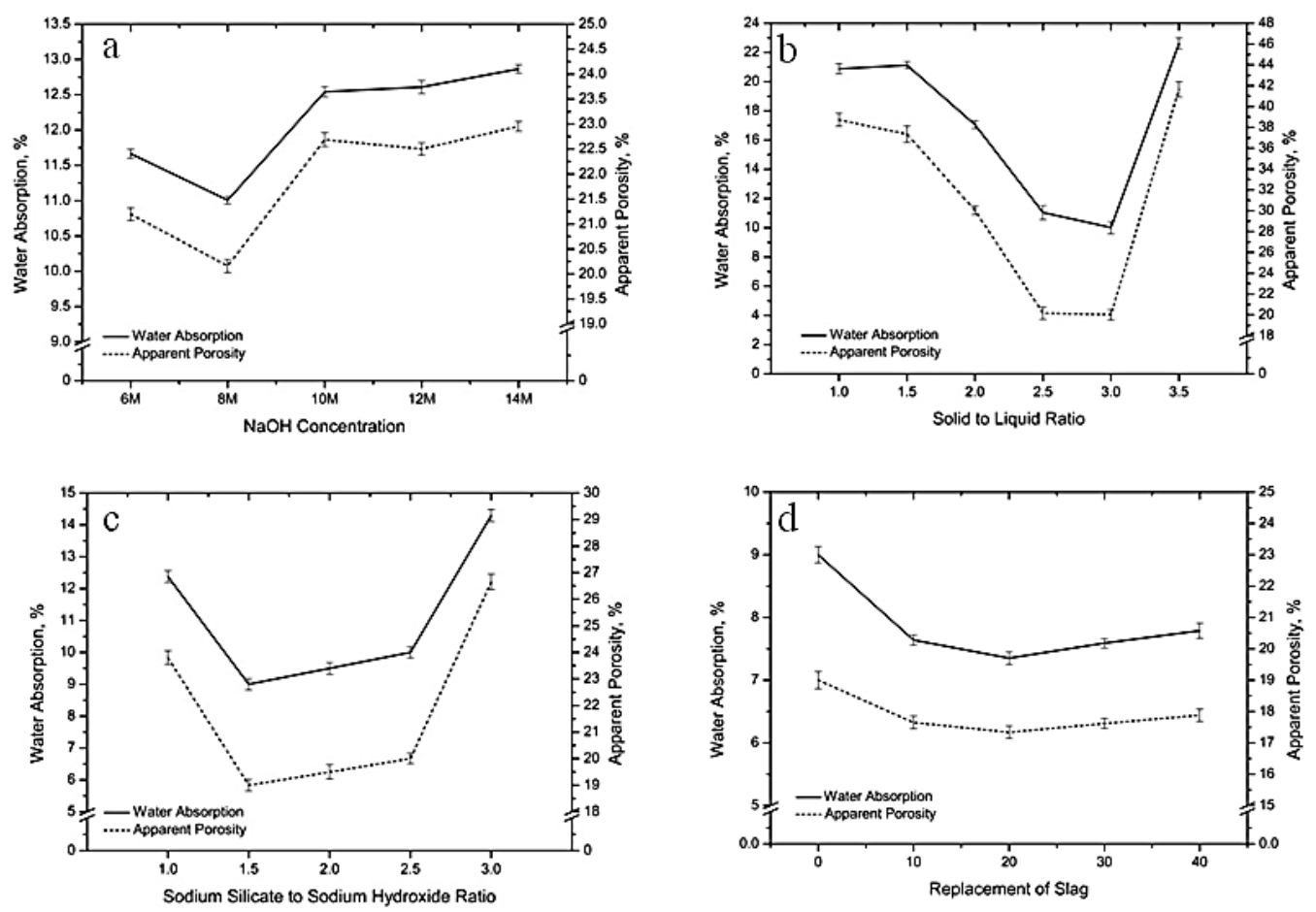

Fig. 2. Apparent porosity and water absorption of fly ash geopolymer with a) $\mathrm{NaOH}$ concentration, b) $\mathrm{S} / \mathrm{L}$ ratios, c) $\mathrm{Na}_{2} \mathrm{SiO}_{3} / \mathrm{NaOH}$ ratios and d) slag replacement.

Based on Fig. 2a, the lowest apparent porosity (20.16\%) and water absorption (11.00\%) were located at $8 \mathrm{M}$ of $\mathrm{NaOH}$ concentration. As a comparison, Aliabdo et al. [39] investigated the influence of $\mathrm{NaOH}$ concentration between $12 \mathrm{M}$ to $18 \mathrm{M}$ based on fly ash geopolymer concrete. They obtained the lowest porosity content with $11.15 \%$ and water absorption consisted of $5.30 \%$ at $16 \mathrm{M}$ of $\mathrm{NaOH}$. Their optimized $\mathrm{NaOH}$ concentration was different from this study (8M) was due to the addition of aggregates and sand.

From Fig. 2b, 3.0 of S/L ratio obtained the lowest values of apparent porosity and water absorption. As compare with Krishnendu et al. [40], they fixed the L/S ratio at 0.32 (S/L ratio around 3) on fly ash geopolymer with alkaline activator $\left(\mathrm{KOH}\right.$ and $\left.\mathrm{Na}_{2} \mathrm{SiO}_{3}\right)$. They revealed that the apparent porosity consisted of $10.5 \%$ whereas water absorption contained $7.06 \%$ which is lower than the values obtained in this work. The reason behind suggested that the type of alkali hydroxide was different in used with this study as they were used potassium hydroxide while this 
research was using sodium hydroxide. It is well known that different alkali solution used could contribute to different properties such as porosity of geopolymers.

Furthermore, Fig. 2c observed that the apparent porosity and water absorption of fly ash geopolymer reduced from $\mathrm{Na}_{2} \mathrm{SiO}_{3} / \mathrm{NaOH}$ ratio of 1.0 to 1.5 , but increased linearly until 3.0. Higher amount of silicate could provide a higher amount of aluminosilicate gel formed which indirectly constituted the better bonding within inter-particle [41]. Thus, it could be suggested that the silicate occupied the cavities between the fly ash particles, as a result, acquired lower water absorption at $\mathrm{Na}_{2} \mathrm{SiO}_{3} / \mathrm{NaOH}$ ratio of 1.5. However, water absorption kept increasing when further increased the silicate content ( 3.0 of $\mathrm{Na}_{2} \mathrm{SiO}_{3} / \mathrm{NaOH}$ ratio) in fly ash geopolymer indicated that higher void content observed. As a comparison, different observations on fly ash geopolymer concrete where water absorption $(5.40 \%$ to $4.85 \%)$ and porosity $(11.30 \%$ to $10.02 \%)$ continuously reduced from 2.0 to 3.33 of $\mathrm{Na}_{2} \mathrm{SiO}_{3} / \mathrm{NaOH}$ ratio [39].

Generally, the apparent porosity $(\sim 17 \%)$ and water absorption ( 7\%) of fly ash/slag geopolymers (Fig. 2d) were comparatively lower than fly ash geopolymers. The apparent porosity and water absorption reduced from $10 \%$ of slag content to $20 \%$, but beyond that increased to $40 \%$. This observation was similar to Niklioć et al. [25] where they stated that increasing the amount of electric arc furnace slag tended to decrease the porosity until a limit but increased again.

\section{Compressive Strength}

Fig. 3 plotted the compressive strength of fly ash geopolymers with various parameters. The optimal compressive strength of $38.89 \mathrm{MPa}$ was achieved at $8 \mathrm{M}$ of $\mathrm{NaOH}$ concentration, 3.0 of $\mathrm{S} / \mathrm{L}$ ratio and 1.5 of $\mathrm{Na}_{2} \mathrm{SiO}_{3} / \mathrm{NaOH}$ ratio for fly ash geopolymer whereas fly ash/slag geopolymer contained the optimum strength $(40.46 \mathrm{MPa})$ at $20 \%$ of slag replacement. Generally, compressive strength followed the trend of bulk density where higher bulk density contributed to the strength gained. Bulk density was closely correlated to compressive strength [42]. Additionally, low strength observed was related to the high apparent porosity and water absorption (Fig. 2).

Accordingly, lower strength observed at each of the initial mixing parameters $(6 \mathrm{M}$ of $\mathrm{NaOH}$ concentration, 1.0 of $\mathrm{S} / \mathrm{L}$ ratio and 1.0 of $\mathrm{Na}_{2} \mathrm{SiO}_{3} / \mathrm{NaOH}$ ratio). There was insufficient of $\mathrm{Na}^{+}$ions for the dissolution of fly ash when low $\mathrm{NaOH}$ concentration was used. It was in accordance with previous study [43]. When utilized low S/L ratio indicated that the liquid content was higher than solid content which could cause slow dissolution process. This statement was in alignment with Aliabdo et al. [39]. Low $\mathrm{Na}_{2} \mathrm{SiO}_{3} / \mathrm{NaOH}$ ratio indicated that $\mathrm{Na}_{2} \mathrm{SiO}_{3}$ is lesser compared to the $\mathrm{NaOH}$ content. It meant that the greater amount of $\mathrm{NaOH}$ content caused the greater amount of water escaped from the mixture as the unbound water from the geopolymers samples were easily expelled out from $\mathrm{NaOH}$ rather than from $\mathrm{Na}_{2} \mathrm{SiO}_{3}$. Similar observation was found by Ahuja \& Dong [44].

However, optimum strength obtained at $8 \mathrm{M}$ of $\mathrm{NaOH}$ concentration was due to its better reaction between solid particles and aqueous phase in the final geopolymeric structure. This was consistent with previous research [39]. The highest strength fell at 3.0 of S/L ratio can be explained by the high amount of solid improved the interaction between alkaline solution and the reaction products, as a result, lower porosity content observed (Fig. 2b). S/L ratio could affect the volume of porosity in the paste and indirectly affected the mechanical performance of geopolymer [39]. High $\mathrm{Na}_{2} \mathrm{SiO}_{3} / \mathrm{NaOH}$ ratio leading the reacting materials with more soluble $\mathrm{Si}$ and greater mechanical strength was obtained at 1.5 of $\mathrm{Na}_{2} \mathrm{SiO}_{3} / \mathrm{NaOH}$ ratio. Similar conclusion was confirmed by Glid et al. [21]. 

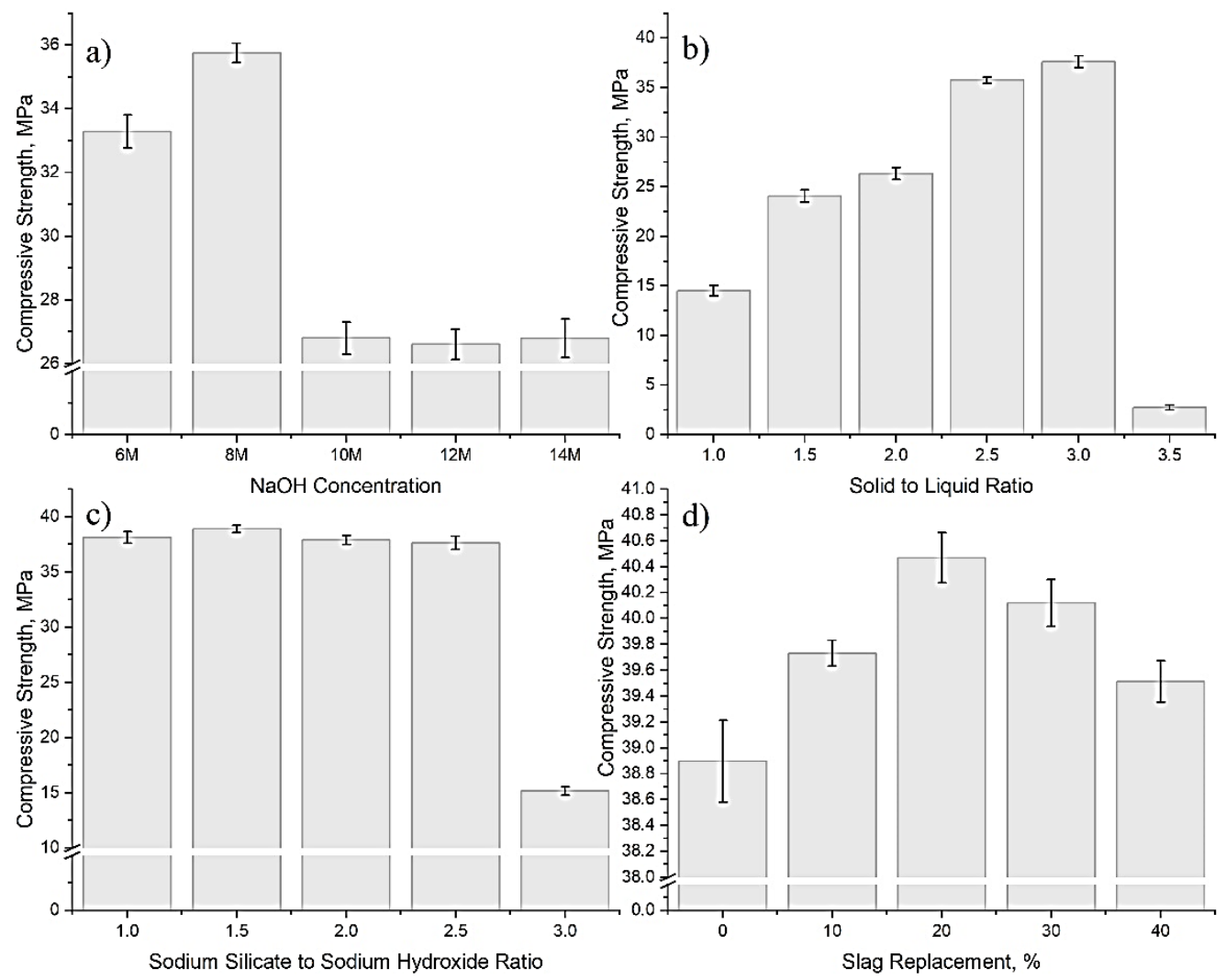

d)

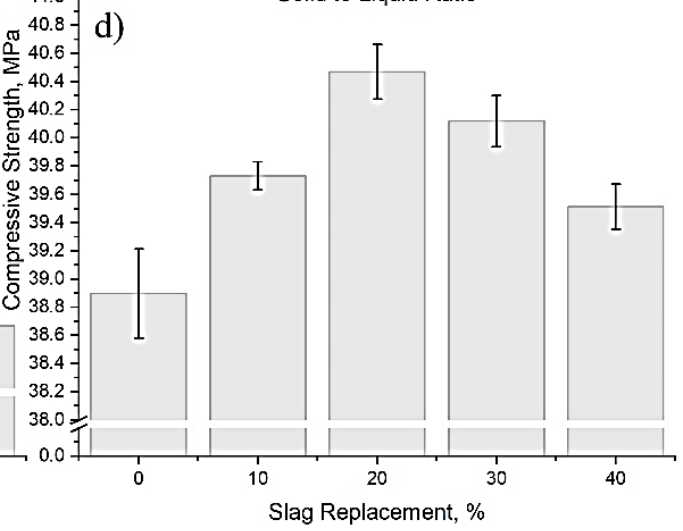

Fig. 3. Compressive strength of fly ash geopolymer with a) $\mathrm{NaOH}$ concentration,

b) $\mathrm{S} / \mathrm{L}$ ratios, c) $\mathrm{Na}_{2} \mathrm{SiO}_{3} / \mathrm{NaOH}$ ratios and d) slag replacement.

Besides, reduction in strength observed when beyond each of the optimal ratios. The excess of $\mathrm{Na}^{+}$ions concentration deteriorated the structure of geopolymer when high $\mathrm{NaOH}$ concentration was used which was correlated with previous researchers [39]. The ions could further react with atmospheric $\mathrm{CO}_{2}$ to create sodium carbonate $\left(\mathrm{Na}_{2} \mathrm{CO}_{3}\right)$ [45] and hence, this was the reason behind of strength dropped. In the case of high $\mathrm{S} / \mathrm{L}$ ratio, the limited amount of solution was not enough to interact with the excess fly ash during geopolymerization process and thus, caused extremely high viscous of the mixtures. This high viscous caused the mixture difficulty in compaction during the moulding process, as a result, low extent of binder formation caused low strength [46]. When increasing $\mathrm{Na}_{2} \mathrm{SiO}_{3} / \mathrm{NaOH}$ ratio indicated that $\mathrm{Na}_{2} \mathrm{SiO}_{3}$ content was higher than $\mathrm{NaOH}$ content. The excess $\mathrm{Na}_{2} \mathrm{SiO}_{3}$ hindered the water evaporation meanwhile the viscous nature of $\mathrm{Na}_{2} \mathrm{SiO}_{3}$ caused a highly sticky mixture formed which prevented the further formation of the geopolymer matrix. Similar statement was agreed by Škvára et al.[47].

As a comparison, Somna et al. [48] achieved an optimum compressive strength of $25.5 \mathrm{MPa}$ at $14 \mathrm{M}$ of $\mathrm{NaOH}$ molarity which was higher than the optimized $\mathrm{NaOH}$ molarity $(8 \mathrm{M})$ in this work. The various observation was due to the used of fly ash with different chemical composition. They carried out the weight percent of $\mathrm{SiO}_{2}(31.2 \mathrm{wt} \%)$ and $\mathrm{Al}_{2} \mathrm{O}_{3}(18.9 \mathrm{wt} \%)$ which were comparatively lower than this work based on XRF analysis (Table 1). The mechanical and physical properties of geopolymers are very depended on the amorphous $\mathrm{Si} / \mathrm{Al}$ ratios. On the other hand, the compressive strength results revealed that the optimal $\mathrm{S} / \mathrm{L}$ ratio and $\mathrm{Na}_{2} \mathrm{SiO}_{3} / \mathrm{NaOH}$ ratio to synthesis fly ash geopolymer was 3.0 and 1.5 , respectively. It was employed in accordance with previous study where Cai et al. [49] used S/L ratio of 3.0 to produce 
fly ash geopolymer whereby Pavithra et al. [50] optimized the 1.5 of $\mathrm{Na}_{2} \mathrm{SiO}_{3} / \mathrm{NaOH}$ ratio in fly ash geopolymer.

In the case of metakaolin geopolymers, Kong et al. [51] investigated that the $\mathrm{S} / \mathrm{L}$ ratio of 0.8 achieved an optimum compressive strength $(38.5 \mathrm{MPa})$ whereas $\mathrm{Na}_{2} \mathrm{SiO}_{3} / \mathrm{NaOH}$ ratio of 0.24 was used in the study of Wang et al. [52]. As a comparison, fly ash geopolymers obtained optimum $\mathrm{S} / \mathrm{L}$ ratio (3.0) and $\mathrm{Na}_{2} \mathrm{SiO}_{3} / \mathrm{NaOH}$ ratio (1.5) in this study were comparatively higher than metakaolin geopolymers. The chosen of $\mathrm{S} / \mathrm{L}$ ratio and $\mathrm{Na}_{2} \mathrm{SiO}_{3} / \mathrm{NaOH}$ ratio were strongly dependent on the workability of the mixtures. This was due to the metakaolin source materials were layered structure which required high water demand (low S/L ratio) in order to provide higher strength [53] and hence, they required lower $\mathrm{Na}_{2} \mathrm{SiO}_{3} / \mathrm{NaOH}$ ratio to compensate the workability problem. In other words, higher $\mathrm{S} / \mathrm{L}$ ratio and $\mathrm{Na}_{2} \mathrm{SiO}_{3} / \mathrm{NaOH}$ ratio were applied in fly ash geopolymer synthesis was due to the spherical-shaped fly ash particles could enhance the workability in the mixture [46].

On the other side, the overall strength of fly ash geopolymer $(2.73 \mathrm{MPa}$ to $38.89 \mathrm{MPa})$ was slightly lower than fly ash/slag geopolymer (39.51MPa to 40.46MPa) as shown in Fig. 3d. It was in accordance with apparent porosity and water absorption values (Fig. 2) where higher porosity content on fly ash geopolymer tended to deteriorate the strength. Puligilla \& Mondal [54] stated that the slower setting of the fly ash geopolymer mixture was caused by the low reactivity of fly ash which directly led to weaker compressive strength than fly ash/slag geopolymer. It is believed that the source of $\mathrm{CaO}$ content that came from slag in the initial solid mixture has been enhanced the strength of geopolymers. $\mathrm{CaO}$ introduced soluble $\mathrm{Ca}^{2+}$ ions in a geopolymer mixture that caused the formation of calcium silicate hydrate (C-S-H) gel along with sodium aluminosilicate hydrate (N-A-S-H) gel which contributed to the strength gained [55-57]. Consequently, it is believed that the optimum strength obtained at $20 \%$ content of slag on fly ash geopolymer was due to the formation of C-S-H gel in addition to N-A-S-H gel.

However, the specimen with slag content exceeded $20 \%$ exhibited strength dropped was due to the rapid geopolymerization reaction caused by an increase of slag content. It was also proven by the fact that increasing the amount of slag in the paste caused the rate of setting quicker [58]. Therefore, the fly ash/slag geopolymer with a rapid rate of setting caused not enough time for geopolymeric structure to well interact. It is reasonable to suggest that the rapid rate of geopolymerization caused poor compressive strength at fly ash geopolymer with $30 \%$ and $40 \%$ of slag content.

In this work, the optimum slag replacement to fly ash ratio was 20:80 which was in agreement with previous authors $[25,57,59]$ reported that by using the slag content between $20 \%$ to $30 \%$ incorporate into fly ash geopolymer was beneficial to the final product. Niklioć et al. [25] utilized electric arc furnace slag to replace fly ash geopolymer, $30 \%$ content of slag were used in further investigation where this ratio provided optimum strength (32MPa) and exhibited strength decreased when slag exceeded $30 \%$. Similarly, Lee et al. [59] concluded that ground-granulated blast furnace slag with $20 \%$ content substituted to fly ash geopolymer obtained optimum strength (30.6MPa) but above $20 \%$ the strength dropped gradually. Therefore, the combination of slag and fly ash acted as an alkali-activated binder could enhance the strength of geopolymer where the slag could control the formation of main binding gels and reaction mechanism.

\section{Conclusion}

The overall bulk densities of fly ash geopolymer $\left(1967.4 \mathrm{~kg} / \mathrm{m}^{3}\right.$ to $\left.2050 \mathrm{~kg} / \mathrm{m}^{3}\right)$ were lower than fly ash/slag geopolymer $\left(2055 \mathrm{~kg} / \mathrm{m}^{3}\right.$ to $\left.2100 \mathrm{~kg} / \mathrm{m}^{3}\right)$. The apparent porosity (19\% to $40 \%$ ) and water absorption ( $9 \%$ to $22 \%$ ) of fly ash geopolymers were comparatively higher than fly ash/slag geopolymers with apparent porosity $(\sim 17 \%)$ and water absorption $(\sim 7 \%)$. Hence, it can be concluded that the high bulk density and low apparent porosity and water absorption 
contributed to the compressive strength of fly ash/slag geopolymer where fly ash/slag geopolymer obtained higher strength than fly ash geopolymer.

\section{Acknowledgments}

Grateful acknowledgments are due to Manjung Coal-fired power plant Perak, Malaysia for providing class F fly ash and Southern Steel Berhad Penang, Malaysia for supplying ladle furnace slag in this work.

This research is funded by the Malaysia Toray Science Foundation (MTSF) Science and Technology Research Grant by Toray Science Foundation, Japan.

\section{References}

[1] J. Xie, O. Kayali, Effect of superplasticiser on workability enhancement of Class $F$ and Class C fly ash-based geopolymers, Construction and Building Materials, 122, 2016, pp. 36-42.

[2] O. Burciaga-Díaz, J. I. Escalante-García, Comparative performance of alkali activated slag/metakaolin cement pastes exposed to high temperatures, Cement and Concrete Composites, 84, 2017, pp. 157-166.

[3] Y. Jiang, T. C. Ling, C. Shi, S. Y. Pan, Characteristics of steel slags and their use in cement and concrete - A review, Resources, Conservation and Recycling, 136, 2018, pp. 187-197.

[4] M. H. Abdullah, R. Abuelgasim, A. S. A. Rashid, N. Z. Mohdyunus, Engineering Properties of Tanjung Bin Bottom Ash, MATEC Web Conferences, 250, 2018.

[5] E. Oluwasola, M. R. Hainin, M. M. A. Aziz, Characteristics and Utilization of Steel Slag in Road Construction, Journal Technology, 70, 2014, pp. 117-123.

[6] Z. Li, S. Zhang, Y. Zuo, W. Chen, G. Ye, Chemical deformation of metakaolin based geopolymer, Cement and Concrete Research, 120, 2019, pp. 108-118.

[7] E. Tiffo, J. B. Bike Mbah, P. D. Belibi Belibi, J. N. Yankwa Djobo, A. Elimbi, Physical and mechanical properties of unheated and heated kaolin based-geopolymers with partial replacement of aluminium hydroxide, Materials Chemistry and Physics, 239, 2020, pp. 122103.

[8] H. Bakkali, M. Ammari, I. Frar, NaOH alkali-activated class F fly ash: NaOH molarity, Curing conditions and mass ratio effect, Journal of Materials and Environmental Science, 7, 2016, pp. 397-401.

[9] A. Hosan, S. Haque, F. Shaikh, Compressive behaviour of sodium and potassium activators synthetized fly ash geopolymer at elevated temperatures: A comparative study, Journal of Building Engineering, 8, 2016, pp. 123-130.

[10] S. Narimani Zamanabadi, S. A. Zareei, P. Shoaei, F. Ameri, Ambient-cured alkali-activated slag paste incorporating micro-silica as repair material: Effects of alkali activator solution on physical and mechanical properties, Construction and Building Materials, 229, 2019, pp. 116911.

[11] K. Mermerdaş, Z. Algın, Ş. Ekmen, Experimental assessment and optimization of mix parameters of fly ash-based lightweight geopolymer mortar with respect to shrinkage and strength, Journal of Building Engineering, 31, 2020, pp. 101351.

[12] J. Cai, X. Li, J. Tan, B. Vandevyvere, Thermal and compressive behaviors of fly ash and metakaolin-based geopolymer, Journal of Building Engineering, 30, 2020, pp. 101307.

[13] N. A. M. Sani, Z. Man, R. M. Shamsuddin, K. A. Azizli, K. Z. K. Shaari, Determination of Excess Sodium Hydroxide in Geopolymer by Volumetric Analysis, Procedia Engineering, 148, 2016, pp. 298-301. 
[14] S. A. Arafa, A. Z. M. Ali, A. S. M. A. Awal, L. Y. Loon, Optimum mix for fly ash geopolymer binder based on workability and compressive strength, IOP Conference Series: Earth and Environmental Science, 140, 2018, pp. 012157.

[15] Y. Ling, K. Wang, X. Wang, S. Hua, Effects of mix design parameters on heat of geopolymerization, set time, and compressive strength of high calcium fly ash geopolymer, Construction and Building Materials, 228, 2019, pp. 116763.

[16] F. Kantarc1, İ. Türkmen, E. Ekinci, Optimization of production parameters of geopolymer mortar and concrete: A comprehensive experimental study, Construction and Building Materials, 228, 2019, pp. 116770.

[17] R. H. A. Rahim, K. A. Azizli, Z. Man, M. F. Nuruddin, Effect of Curing Conditions on the Mechanical Properties of Fly Ash-Based Geopolymer without Sodium Silicate Solution, Applied Mechanics and Materials, 699, 2015, pp. 15-19.

[18] E. Kamseu, L. M. Beleuk à Moungam, M. Cannio, N. Billong, D. Chaysuwan, U. C. Melo, C. Leonelli, Substitution of sodium silicate with rice husk ash-NaOH solution in metakaolin based geopolymer cement concerning reduction in global warming, Journal of Cleaner Production, 142, 2017, pp. 3050-3060.

[19] L. Darmayanti, G. T. M. Kadja, S. Notodarmojo, E. Damanhuri, R. R. Mukti, Structural alteration within fly ash-based geopolymers governing the adsorption of $\mathrm{Cu} 2+$ from aqueous environment: Effect of alkali activation, Journal of Hazardous Materials, 377, 2019, pp. 305-314.

[20] K. Komnitsas, D. Zaharaki, Geopolymerisation: A review and prospects for the minerals industry, Minerals Engineering, 20, 2007, pp. 1261-1277.

[21] M. Glid, I. Sobrados, H. B. Rhaiem, J. Sanz, A. B. H. Amara, Alkaline activation of metakaolinite-silica mixtures: Role of dissolved silica concentration on the formation of geopolymers, Ceramics International, 43, 2017, pp. 12641-12650.

[22] Saloma, Hanafiah, D. O. Elysandi, D. G. Meykan, Effect of $\mathrm{Na}_{2} \mathrm{SiO}_{3} / \mathrm{NaOH}$ on mechanical properties and microstructure of geopolymer mortar using fly ash and rice husk ash as precursor, AIP Conference Proceedings, 1903, 2017, pp. 050013.

[23] S. Yaseri, G. Hajiaghaei, F. Mohammadi, M. Mahdikhani, R. Farokhzad, The role of synthesis parameters on the workability, setting and strength properties of binary binder based geopolymer paste, Construction and Building Materials, 157, 2017, pp. 534-545.

[24] M. Arnoult, M. Perronnet, A. Autef, S. Rossignol, How to control the geopolymer setting time with the alkaline silicate solution, Journal of Non-Crystalline Solids, 495, 2018, pp. 59-66.

[25] I. Niklioć, S. Marković, I. Janković-Častvan, V. V. Radmilović, L. Karanović, B. Babić, V. R. Radmilović, Modification of mechanical and thermal properties of fly ash-based geopolymer by the incorporation of steel slag, Materials Letters, 176, 2016, pp. 301-305.

[26] P. Duan, C. Yan, W. Zhou, Influence of partial replacement of fly ash by metakaolin on mechanical properties and microstructure of fly ash geopolymer paste exposed to sulfate attack, Ceramics International, 42, 2016, pp. 3504-3517.

[27] F. N. Okoye, J. Durgaprasad, N. B. Singh, Mechanical properties of alkali activated flyash/Kaolin based geopolymer concrete, Construction and Building Materials, 98, 2015, pp. 685-691.

[28] A. Hasnaoui, E. Ghorbel, G. Wardeh, Optimization approach of granulated blast furnace slag and metakaolin based geopolymer mortars, Construction and Building Materials, 198, 2019, pp. 10-26. 
[29] J. Qiu, Y. Zhao, J. Xing, X. Sun, Fly Ash/Blast Furnace Slag-Based Geopolymer as a Potential Binder for Mine Backfilling: Effect of Binder Type and Activator Concentration, Advances in Materials Science and Engineering, 2019, 2019, pp. 12.

[30] W. C. Wang, H. Y. Wang, H. C. Tsai, Study on engineering properties of alkali-activated ladle furnace slag geopolymer, Construction and Building Materials, 123, 2016, pp. 800-805.

[31] ASTM. C618-12a, Standard Specification for Coal Fly Ash and Raw or Calcined Natural Pozzolan for Use in Concrete ${ }^{1}$, ASTM International, West Conshohocken, PA, 2013.

[32] ASTM. C109/C109-05, Standard test method for compressive strength of hydraulic cement mortars (Using 2-in. or $[50 \mathrm{~mm}]$ cube specimens) ${ }^{1}$, ASTM International, West Conshohocken, PA, 2013.

[33] BS. EN. 12390-7, Testing hardened concrete. Density of hardened concrete, London: British Standards, 2000.

[34] ASTM. C642-97, Standard Test Method for Density, Absorption, and Voids in Hardened Concrete, ASTM International, West Conshohocken, PA, 1997.

[35] E. Muthu Kumar, K. Ramamurthy, Influence of production on the strength, density and water absorption of aerated geopolymer paste and mortar using Class F fly ash, Construction and Building Materials, 156, 2017, pp. 1137-1149.

[36] S. Pilehvar, V. D. Cao, A. M. Szczotok, M. Carmona, L. Valentini, M. Lanzón, R. Pamies, A. L. Kjøniksen, Physical and mechanical properties of fly ash and slag geopolymer concrete containing different types of micro-encapsulated phase change materials, Construction and Building Materials, 173, 2018, pp. 28-39.

[37] S. V. Patankar, Y. M. Ghugal, S. S. Jamkar, Effect of Concentration of Sodium Hydroxide and Degree of Heat Curing on Fly Ash-Based Geopolymer Mortar, Indian Journal of Materials Science, 2014, 2014, pp. 6.

[38] X. Guo, J. Yang, Intrinsic properties and micro-crack characteristics of ultra-high toughness fly ash/steel slag based geopolymer, Construction and Building Materials, 230, 2020, pp. 116965.

[39] A. A. Aliabdo, A. E. M. Abd Elmoaty, H. A. Salem, Effect of water addition, plasticizer and alkaline solution constitution on fly ash based geopolymer concrete performance, Construction and Building Materials, 121, 2016, pp. 694-703.

[40] B. Krishnendu, B. Ankush, P. Surosrita, D. Dutta, D. T. G. Biswas, Study of Geopolymer Paste Considering Equivalent Silicate Modulus, Journal of Mechanical and Civil Engineering, 2001, pp. 01-06.

[41] K. Ghosh, Effect of \% Na2O and \%SiO2 on Apperent Porosity And Sorptivity of Flyash Based Geopolymer, IOSR Journal of Engineering, 02, 2012, pp. 96-101.

[42] M. Ghanbari, A. M. Hadian, A. A. Nourbakhsh, K. J. D. MacKenzie, Modeling and optimization of compressive strength and bulk density of metakaolin-based geopolymer using central composite design: A numerical and experimental study, Ceramics International, 43, 2017, pp. 324-335.

[43] M. Rowles, B. O'Connor, Chemical optimisation of the compressive strength of aluminosilicate geopolymers synthesised by sodium silicate activation of metakaolinite, Journal of Materials Chemistry, 13, 2003, pp. 1161-1165.

[44] S. Ahuja, M. W. Dong, Handbook of Pharmaceutical Analysis by HPLC, Separation Science and Technology, 6, Elsevier Science, 2005.

[45] V. F. F. Barbosa, K. J. D. MacKenzie, C. Thaumaturgo, Synthesis and characterisation of materials based on inorganic polymers of alumina and silica: sodium polysialate polymers, International Journal of Inorganic Materials, 2, 2000, pp. 309-317. 
[46] N. Nikoloutsopoulos, A. Sotiropoulou, G. Kakali, S. Tsivilis, The effect of Solid/Liquid ratio on setting time, workability and compressive strength of fly ash based geopolymers, Materials Today: Proceedings, 5, 2018, pp. 27441-27445.

[47] F. Škvára, L. Kopecky, J. Němeček, Z. Bittnar, Microstructure of geopolymer materials based on fly ash, Ceramics-Silikaty, 50, 2006, pp. 208-215.

[48] K. Somna, C. Jaturapitakkul, P. Kajitvichyanukul, P. Chindaprasirt, NaOH-activated ground fly ash geopolymer cured at ambient temperature, Fuel, 90, 2011, pp. 2118-2124.

[49] J. Cai, J. Pan, X. Li, J. Tan, J. Li, Electrical resistivity of fly ash and metakaolin based geopolymers, Construction and Building Materials, 234, 2020, pp. 117868.

[50] P. Pavithra, M. Srinivasula Reddy, P. Dinakar, B. Hanumantha Rao, B. K. Satpathy, A. N. Mohanty, Effect of the $\mathrm{Na}_{2} \mathrm{SiO}_{3} / \mathrm{NaOH}$ Ratio and $\mathrm{NaOH}$ Molarity on the Synthesis of Fly Ash-Based Geopolymer Mortar, Geo-Chicago 2016, 2016.

[51] D. L. Y. Kong, J. G. Sanjayan, K. Sagoe-Crentsil, Comparative performance of geopolymers made with metakaolin and fly ash after exposure to elevated temperatures, Cement and Concrete Research, 37, 2007, pp. 1583-1589.

[52] H. Wang, H. Li, F. Yan, Synthesis and mechanical properties of metakaolinite-based geopolymer, Colloids and Surfaces A: Physicochemical and Engineering Aspects, 268, 2005, pp. 1-6.

[53] M. A. Longhi, E. D. Rodríguez, B. Walkley, Z. Zhang, A. P. Kirchheim, Metakaolin-based geopolymers: Relation between formulation, physicochemical properties and efflorescence formation, Composites Part B: Engineering, 182, 2020, pp. 107671.

[54] S. Puligilla, P. Mondal, Role of slag in microstructural development and hardening of fly ash-slag geopolymer, Cement and Concrete Research, 43, 2013, pp. 70-80.

[55] C. B. Cheah, M. H. Samsudin, M. Ramli, W. K. Part, L. E. Tan, The use of high calcium wood ash in the preparation of Ground Granulated Blast Furnace Slag and Pulverized Fly Ash geopolymers: A complete microstructural and mechanical characterization, Journal of Cleaner Production, 156, 2017, pp. 114-123.

[56] D.D. Burduhos Nergis, P. Vizureanu, I. Ardelean, A. V. Sandu, O. Corbu, E. Matei, Revealing the Influence of Microparticles on Geopolymers' Synthesis and Porosity, Materials, 13, 2020, p. 3211.

[56] S. Saha, C. Rajasekaran, Enhancement of the properties of fly ash based geopolymer paste by incorporating ground granulated blast furnace slag, Construction and Building Materials, 146, 2017, pp. 615-620.

[57] D. D. Burduhos Nergis, M. M. A. B. Abdullah, A. V. Sandu, P. Vizureanu, XRD and TGDTA Study of New Alkali Activated Materials Based on Fly Ash with Sand and Glass Powder, Materials, 13(2), 2020, p. 343.

[58] D. D. Burduhos Nergis, P. Vizureanu, O. Corbu, Synthesis and Characteristics of Local Fly Ash Based Geopolymers Mixed with Natural Aggregates, Revista de Chimie, 70(4), 2019, pp. 1262-1267.

[59] N. K. Lee, H. K. Lee, Setting and mechanical properties of alkali-activated fly ash/slag concrete manufactured at room temperature, Construction and Building Materials, 47, 2013, pp. 1201-1209.

Received: September 05, 2020

Accepted: October 23, 2020 